weń wzorców męskości z rzeczywistością wspomnieniową bliższą niewątpliwie odzwierciedleniu realnej (społecznej, materialnej i duchowej) sytuacji uczestników ruchu budzicielskiego. Autor zdaje sobie bowiem sprawę, że: Między wyobrażeniami i pragnieniami i stosunkiem do nich, a tym bardziej realizacja, może [...] wystepować zarówno zgodność, jak i rozbieżność (s. 200). Pamiętniki, bliższe z natury rzeczy autentycznym uwarunkowaniom biograficznym, pozwalają mu na weryfikację tez i wyobrażeń przekazywanych w pisarstwie fikcjonalnym i w publicystyce, dostarczają bowiem bogatego materiału dokumentalnego zarówno w sferze rekonstrukcji wydarzeń historycznych, jak i doświadczenia osobistego. Monografista zdaje sobie oczywiście sprawę (co zostaje potwierdzone dzięki przywołaniu najnowszych ustaleń badawczych dotyczących prozy autobiograficznej), że wiara w absolutną szczerość i referencjalność prozy wspomnieniowej musi mieć charakter umowny i uwzględniać zarówno quasi-literackie konwencje patronujące (nawet mimowolnie) konstruowaniu autobiografii, jak i wszelakiego rodzaju przekłamania wypływające bądź z chęci zatajenia niektórych ,niewygodnych” dla autora wspomnień faktów czy przemyśleń, bądź z niedoskonałości ,ppracy pamięci”. Filipowicz powraca tu do wcześniej omawianych kręgów problemowych, kolejne podrozdziały poświęcając pamiętnikarskim rozważaniom na temat języka, emocji, honoru, pozycji społecznej, życia rodzinnego czy marzeń o konkretnym czynie patriotycznym. Wzbogaca w ten sposób obraz czeskiego męskiego świata zakodowany w dyskursie literackim i publicystycznym i jednocześnie wzmacnia wcześniej sformułowane supozycje, iż oficjalne deklaracje i „życzeniowe” prognozy często rozmijały się z trudną i pełną rozczarowań prawdą o dochodzeniu do czeskości.

Niezależnie od tych wszelkich przychodzących na myśl uwag polemicznych „Panowie Bądźmy Czechami...” jawi się jako cenna i interesująca pozycja w dorobku polskiej bohemistyki. Świadczy o ambicjach poznawczych Marcina Filipowicza, nakazujących mu poddawać głosy uznanych autorytetów wnikliwej i krytycznej weryfikacji. Stanowić może zatem punkt wyjścia dla dalszych badań, pogłębiających i poszerzających, a w niektórych przypadkach w ogóle inicjujących wiedzę na temat genderowego wymiaru czeskiej kultury i literatury.

DOI 10.14746/SO.2014.71.24

Krystyna Pieniążek-Marković

Poznań

\title{
Sabina Giergiel, Ocalić pamięcią. Praktyki pamięci i zapominania we wspótczesnej prozie postju- gostowiańskiej, Wydawnictwo Uniwersytetu Opolskiego, Opole 2012, ss. 276
}

Sabina Giergiel opublikowała niedawno drugą w swoim dorobku naukowym monografię z zakresu południowej slawistyki. Podczas gdy pierwsza dotyczyła twórczości jednego z najważniejszych współczesnych pisarzy serbskich (Obcość jako los. O prozie Borislava Pekicia, Opole 2008), w drugiej przedmiotem zainteresowania autorka uczyniła czterech twórców (David Albahari, Miljenko Jergović, Daša Drndić i Aleksander Hemon) reprezentujących literatury serbską, chorwacką i bośniacką. Wyraźnie widoczne jest zatem poszerzanie kręgu naukowych zainteresowań. Obie pozycje, mimo że odmienne jest ich pole badawcze, łączą jednak dwie kwestie. Po pierwsze, osadzając rozważania na różnych fundamentach teoretyczno-metodologicznych, autorka najchętniej stosuje podejście hermeneutyczne spod znaku Paula Ricoeura. Po drugie, zarówno u Pekicia, jak u czterech autorów będących bohaterami omawianej tu pozycji, Sabina Giergiel, odwołując się do spostrzeżeń i określeń Ryszarda Nycza (Literatura jako trop rzeczywistości), dostrzegła strategie pisania sobą i pisania siebie - choć oczywiście wyrastają one z innych doświadczeń - oraz przeplatanie doświadczenia osobowego z doświadczeniem cudzym (doświadczenie Innego lub doświadczenie ogólniejsze, ponadjednostkowe). W każdej z opublikowanych monografii ważnymi zagadnieniami są także wolność, zniewolenie, odpowiedzialność za siebie oraz Innego, potrzeba dialogu, krytyka zamknięcia na to, co Inne, samotność, tożsamość, moralność czy przekonanie 
o wartości świata niejednoznacznego i pluralistycznego. Sabina Giergiel - jakkolwiek górnolotnie może to zabrzmieć - usiłuje odnaleźć w tekstach prawdę o człowieku i jego czasach.

Publikacja Ocalić pamięcią. Praktyki pamięci i zapominania we współczesnej prozie postjugosłowiańskiej wpisuje się w aktualny, może nawet popularny, lecz bardzo potrzebny nurt badań nad literaturą i kulturą europejską, w szczególny sposób naznaczoną traumatycznymi doświadczeniami na terenach krajów powstałych po rozpadzie Jugosławii. Pamięć i przemilczanie burzliwej i tragicznej dwudziestowiecznej historii Serbii, Chorwacji i Bośni, zwłaszcza wydarzeń II wojny światowej, znacząco przyczyniły się do wybuchu zbrojnego konfliktu w latach dziewięćdziesiątych XX wieku, a może nawet o nim przesądziły. Dlatego podjęcie zamiaru opisania na wybranych przykładach Praktyk pamięci $i$ zapominania we współczesnej prozie postjugosłowiańskiej należy uznać za wybór trafny oraz wskazujący na skłonność autorki do uprawiania humanistyki zaangażowanej. Odwrót od przyszłości i rozrachunkowe, nostalgiczne czy melancholijne zwroty ku przeszłości już od dłuższego czasu fascynują badaczy literatury i kultury, ale jak pokazuje również omawiana praca, przed nauką sporo jeszcze do zrobienia. Także z tego powodu, że pisarze dostarczają nowych materiałów do eksploracji, w których fundamentalną tezą jest założenie, że bez pamięci - indywidualnej i zbiorowej - nie sposób zrozumieć siebie oraz teraźniejszości, a tym bardziej projektować przyszłości. W przypadku wybranych do oglądu utworów, niezależnie od dokonanych przez autorkę ustaleń, ciągle możliwe są do uruchomienia nowe perspektywy interpretacyjne. Szczególnie przydatne mogą się okazać nurty badające genealogie pamięci, dialog pomiędzy pamięciami grup i narodów, pamięć zbiorową kształtowaną na „skrwawionych ziemiach” (Timothy Snyder, Skrwawione ziemie).

Do szczegółowej analizy Sabina Giergiel wybrała czterech współczesnych autorów, trzech znanych w Polsce z przekładów ich dzieł: Miljenka Jergovicia, Davida Albahariego i Dašę Drndić oraz jednego (pochodzącego z Bośni, lecz mieszkającego w Ameryce i piszącego po angielsku), który jeszcze nie doczekał się tłumaczeń na język polski - Aleksandra Hemona. Całą czwórkę - zdaniem autorki - charakteryzuje hybrydowa tożsamość i bytowanie pomiędzy światami. Miljenko Jergović „Chorwat urodzony w Bośni” (s. 17), w latach dziewięćdziesiątych zamieszkał w Zagrzebiu, jednak zaliczany jest także do literatury bośniackiej, a uważa się za członka wciąż żywej kulturowej Jugosławii. David Albahari, który w latach dziewięćdziesiątych wyemigrował do Kanady, to Serb podkreślający swe żydowskie pochodzenie, natomiast Chorwatka Daša Drndić przez lata mieszkała w Belgradzie. Habilitantka bohaterami swej książki uczyniła autorów, u których dostrzega ślady kryzysu spowodowanego podziałem Jugosławii, wspólne doświadczenie Historii jako siły destrukcyjnej oraz pragnienie ocalenia przeszłości dla ocalenia tożsamości (s. 18). Elementem łączącym pisarzy ma być także ich emigracja, choć w każdym przypadku oznaczająca inną dyslokację. Nie do porównania są bowiem decyzja o pozostaniu w Ameryce Hemona, który wyjechał do USA na studia przed rozpadem kraju i wybuchem wojny, emigracja Albahariego do Kanady, przeniesienie się Jergovicia z Sarajewa do Zagrzebia czy Dašy Drndrić z Belgradu do Rijeki. Celem Sabiny Giergiel nie była wyczerpująca prezentacja całokształtu twórczości wybranych autorów, a jedynie utworów pozwalających na realizację koncepcji książki, która zasadza się na ukazaniu czterech odsłon wykorzystania pamięci, czterech figur pamięci: 1. Nostalgiczne przywoływanie minionego. Miljenko Jergović, 2. Brzemię pamięci. David Albahari, 3. Istnieć naprawdę to być „,gdzie indziej”. Aleksandar Hemon, 4. Ocalić pamięcią. Daša Drndić.

W badaniach nad pamięcią autorka odwołuje się do Ricoeura, Franka Ankersmita, Hydena Whita, Maurice’a Halbawchsa oraz korzysta z cennego opracowania Pamięć zbiorowa i kulturowa (ten zakres literatury przedmiotowej można byłoby oczywiście poszerzyć z pożytkiem dla pogłębionej refleksji, zwłaszcza nad skomplikowanymi relacjami pomiędzy historią i pamięcią kulturową). Sabina Giergiel mówi o fenomenie pamięci (s. 7), słowie-kluczu (s. 15), fenomenologii pamięci (s. 15), topice pamięciowej (s. 21). W jej rozważaniach istotną rolę zajmuje zarówno pamięć indywidualna, jak i zbiorowa, kulturowa, komunikatywna. Pamięć, z czym można polemizować, stawiana jest na równi z retrospekcją i reprezentacją przeszłości oraz utożsamiana z odzwierciedleniem stosunku jednostki do przeszłości, która została skazana na zapomnienie: „Pojęcie pamięci, retrospekcji, reprezentacji przeszłości pozwala mi na uchwycenie stosunku jednostki wobec przeszłości (wersji historii, która tak wyraźnie została skazana przez z oficjalne dyskursy na zapomnienie)" (s. 15).

Kategoria pamięci jest w pracy ściśle powiązana z momentem przełomowym, doświadczeniem rozpadu, utraty, zmiany czy dyslokacji oraz tożsamością. Przełomami są dla powieściopisarzy i bohaterów omawianych powieści rozpad Jugosławii i doświadczenia wojny z lat dziewięćdziesiątych (określana, niestety, błędnym terminem ,wojna bałkańska”, sytuującym ostatni konflikt w nieodpowiednim kontekście; na marginesie muszę dodać, że zdarzające się terminologiczne nieścisłości, stylistyczne i redakcyjne niedociągnięcia skutkują dyskomfortem w czasie lektury), która dla każdego z autorów stała się przyczyną emigracji lub zmiany miejsca zamieszkania oraz intensyfikacji procesów autoidentyfikacyjnych. Eksplikując zagadnienia pamięci i zapomnienia (a zarazem 
prawdy i kłamstwa) w twórczości wybranych prozaików, autorka równie wiele uwagi poświęca kwestiom podmiotowości, obecności wątków autobiograficznych (w tym celu odwołuje się nie tylko do tekstowych reprezentacji fikcjonalnych, lecz także do różnego rodzaju zapisów niefikcjonalnych) czy związkom twórcy z tekstem, „sobąpisaniu” (Foucault), doświadczeniu i świadectwa (słusznie ważne miejsce w tych fragmentach zajmują rozważania Barbary Skargi), etycznym wymiarom literatury, wojennej traumie, śladom kryzysu, wykluczeniu, stygmatyzacji, wielkim figurom egzystencjalnym, sytuacjom granicznym, oficjalnemu dyskursowi oraz gestom sprzeciwu wobec niego. Zgodnie z ustaleniami polskich badaczy (Hanna Gosk i in.) „gesty sprzeciwu” tworzą kontrdyskurs wobec narracji oficjalnych. Rozprawa Sabiny Giergiel sytuuje się - może niekoniecznie zgodnie z zamierzeniami Autorki, gdyż brak przywołania istotnych ustaleń z prac Hanny Gosk czy tomów opublikowanych przez Centrum Badań Dyskursów Postzależnościowych - w ramach badań dyskursu postzależnościowego. Traktuje o kontrdyskursach/,zakazanych narracjach” zdradzających ślady kondycji postzależnościowej, gdyż lokujących się w opozycji do narracji nowych państw narodowych. Problemy, które wyżej wymieniłam jako towarzyszące dyskursowi o pamięci autorka również sytuuje wśród istotnych zagadnień badawczych.

Tekst literacki Sabina Griegel traktuje jako emanację doświadczenia autora empirycznego (s. 13), poszukuje w tekście tropów jednostkowego świadczenia o własnym traumatycznym doświadczeniu (s. 16), lecz znaczna część pracy dotyczy także pamięci zbiorowej. W rozdziałach poświęconych Drndić (ur. 1946) i Albahariemu (ur. 1948) autorka sięga po utwory dotyczące II wojny światowej. Relacje pisarzy, w świetle rozważań badaczki, należałoby określić zapisem z drugiej ręki, przekazem opowieści zasłyszanych od krewnych (s. 18), obok pamięci indywidualnej istotna okazuje się zatem pamięć rodzinna (grupy społecznej). W rozdziale poświęconym Albahariemu znajdują się (są to głównie zamieszczone w przypisach cytaty) także próby definiowania pamięci autobiograficznej, zbiorowej, kulturowej i postpamięci.

Publikacja przynosi wartościowe i potrzebne badania twórczości wybranych autorów, które najbliższe są antropologii literatury. Autorka podejmuje niezwykle ważne zagadnienia penetrujące kondycję człowieka poszukującego odpowiedzi na fundamentalne pytanie „kim jestem?”. Nabiera ono szczególnego dramatyzmu w kontekście kryzysowych i traumatycznych wydarzeń ostatniego ćwierćwiecza. Kategorią porządkującą opis złożonych problemów współczesności jest jednostkowa i zbiorowa pamięć sytuowana w trafnie dobranych kontekstach teoretycznoliterackich, filozoficznych, kulturowych. Sabina Giergiel wykazuje się znajomością zarówno tekstów literackich, jak i właściwego instrumentarium interpretacyjnego, którym sprawnie się posługuje. Zagadnienie pamięci (pamiętania i zapominania) oraz towarzyszące mu problemy tożsamości, podmiotowości, rozpadu, obcości czy wykluczenia autorka ujmuje w szerokim spektrum badań interdyscyplinarnych. Nie rezygnując z narzędzi filologicznych, odwołuje się do historiografii, filozofii (filozofii literatury), psychoanalizy, aparatu socjologiczno-politycznego, kulturoznawczego i antropologicznego. W czterech rozdziałach książki tworzy cztery portrety, w każdym odnajdując inną dominującą figurę pamięci (ratunek przed rozpadem - Jergović, brzemię Albahari, źródło nostalgii i melancholii - Hemon, ocalenie - Drndić), ale także znaczne zbieżności w sposobie widzenia świata i etycznym nacechowaniu tekstów. Choć mowa o pisarzach reprezentujących różne pokolenia, autorka przekonuje, że o podobieństwach w ideowej warstwie utworów przesądziło wspólne doświadczenie z okresu wielokulturowej Jugosławii.

Rozprawa nabiera charakteru syntezy prezentującej wielopłaszczyznową problematykę zasygnalizowaną przez tytuł i dopełnianą w rozdziałach egzegezą różnorodnych sensów wpisanych w twórczość wybranych autorów i stanowiących odpowiedź na wyzwania traumatycznych postjugosłowiańskich doświadczeń, ale także szerzej - doświadczeń nowoczesnej Europy. Autorka prezentuje czytelniczą i badawczą wrażliwość, eksponuje moralne zobowiązania literatury, zagłębia się w indywidualne odpowiedzi na rozpad znanego świata i stan po katastrofie, który wzywa do przemyślenia własnych i zbiorowych relacji z rzeczywistością oraz do konstrukcji nowych tożsamości. Pozycja Ocalić pamięciq. Praktyki pamięci i zapominania we współczesnej prozie postjugostowiańskiej oferuje rzetelną hermeneutyczną lekturę oraz wyraźną osobową perspektywę odbioru. 